\title{
ELECTRON MICROSCOPIC STUDY ON ENLARGED CELLS OF RED SEA BREAM, Pagrus major INFECTED BY THE RED SEA BREAM IRIDOVIRUS (RSIV, GENUS Megalocytivirus, FAMILY Iridoviridae)
}

\author{
Ketut Mahardika \# \\ Research Institute for Mariculture, Gondol, PO Box 140, Singaraja, Bali, Indonesia
}

\begin{abstract}
Most histopathologycal studies of the red sea bream iridovirus (RSIV) disease in red sea bream have been performed by studying enlarged cells as well as necrotized cells in the spleen and other organs. These enlarged cells have been named as inclusion body bearing cells (IBCs). However, few information is available about detail of ultrastructural features of IBCS produced in the target organs of RSIV-infected fish. In the present study, details of ultrastructural features of IBCs that were produced in the spleen tissue of naturally RSIV-infected red sea bream were investigated under electron microscope. Under electron microscope, RSIV- infected red sea bream had the presence of two types of IBCs: typical IBCS allowing virus assembly within viral assembly site (VAS), and atypical IBCs which degenerate organelles without virus assembly. Other infected-cells were observed as necrotized cells forming intracytoplasmic VAS with large numbers of virions, but without the formation of the distinct inclusion body. Morphogenesis steps on RSIV-infected red sea bream were observed as filamentous-filed virions, partially- filled virions and complete virions with 145- $150 \mathrm{~nm}$ in size. These findings confirmed that RSIV-infected red sea bream were characterized by formation of typical and atypical IBCs as well as necrotized cells.
\end{abstract}

KEYWORDS: red seabream, RSIV, INCs, necrotized cells, VAS virion

\section{INTRODUCTION}

Iridovirids are well known as causative agents of several serious systemic diseases in a wide variety of fishes either wild, cultured or ornament, and have been identified to infect at least 19 fish species in the last decade (Piaskoski \& Plumb, 1999; Hyatt et al., 2000). The family of Iridoviridae consists of five genera: Iridovirus, Chloriridovirus, Ranavirus, Megalocytivirus, and Lymphocystivirus in which each genera consists of one or more virus species and strains (Chinchar et al., 2005).
The genus of Megalocytivirus encompasses at least several viral isolates such as red sea bream iridovirus (RSIV), grouper sleepy disease iridovirus (GSDIV), sea bass iridovirus (SBIV), African lampeye iridovirus (ALIV), dwarf gourami iridovirus (DGIV), Taiwan grouper iridovirus (TGIV), rock bream iriovirus (RBIV), and infectious spleen and kidney necrosis virus (ISKNV) (Chinchar et al., 2005; 2007). RSIV is known to cause an acute and highly contagious disease. Since 1990, outbreaks of this viral infection, which is named as the red sea bream iridoviral disease (RSIVD), have caused

\# Corresponding author. Research Institute for Mariculture, Gondol, PO Box 140, Singaraja, Bali 81101, Indonesia. Tel.: +62 36292278

E-mail address: 
severe economic losses in Asian countries including Japan (Inouye et al., 1992), Korea (Sohn et al., 2000; Jung \& Oh, 2000), Thailand (Sudthongkong et al., 2002a), Taiwan (Chou et al., 1998), and China (He et al., 2001). This disease has caused mass mortality among cultured marine fishes including 18 species of Perciformes, one species of Pleuronectiformes, and one species of Tetradontiformes (Matsuoka et al., 1996). A recent survey showed that more than 31 species of fishes are susceptible to this virus (Kawakami \& Nakajima, 2002). Based on genetic variation and geographic distribution, RSIV isolate from Japan belongs to the genotype I along with other virus isolates from Korea, China, and Thailand. Viruses belonging to the genotype I are widely distributed among various fish species in many Asian countries (Song et al., 2008).

Diseased fish become lethargic and experience severe anemia, petechia of the gill and enlargement of the spleen. RSIV is sensitive to chloroform and ether and unstable to heat but not affected by ultrasonic treatment or repeated freezing and thawing (Nakajima \& Sorimachi, 1994). The genome of RSIV virus encods a major capsid protein (MCP) gene and 92 other putative open reading frames (ORFs) (Kurita et al., 2002). The MCP gene accounts for about $45 \%$ of the total protein of the virus and is needed for the cleavage and packaging of viral DNA to form viable virions (Williams, 1996). This gene has been selected to analyze the phylogenetic relationships of iridoviruses (Go et al., 2006; Imajoh et al., 2007; Lu et al., 2005) and has been confirmed to be the most suitable gene in detection and measurement of RSIV infection (Caipang et al., 2003; Dang Thi et al., 2007).

Diseased fish histopathologically displays enlarged cells containing an unique inclusion body (inclusion body- bearing cells: IBC) and necrosis of virus- infected cells in the spleen and hematopoietic tissue (Jung et al., 1997; Sudthongkong et al., 2002a,b). Similar to the RSIV- infected cells in vivo, RSIV can also replicate in several fish cell lines (in vitro) at suitable temperatures from 20 to $25^{\circ} \mathrm{C}$, however, BF- 2 (blue gill fry-2) and GF (grunt fin) cell lines were demonstrated to be optimal for RSIV infection and proliferation (Nakajima \& Sorimachi, 1994; Imajoh et al., 2004; Mahardika \& Miyazaki, 2009). RSIV-infected cells in these cell lines display cellular enlargement as a definitive cytopathic effect. Under electron microscopic observation, RSIV-infected GF cells revealed the presence of two types of enlarged cells: IBCs, and cells allowing virus propagation within an intracytoplasmic virus assembly site (VAS) and having the fragmented or absent nucleus (Mahardika \& Miyazaki, 2009). Thus, RSIV- infected cells in vivo and in vitro produced IBCs as well as necrotized cells, both of which are observed as enlarged cells under light microscope (Miyazaki, 2007). Ultrastructural features of IBCs derived from GSDIV- infected humpback grouper, Cromileptes altivelis has been described in detail (Mahardika et al., 2004) as well as enlarged cells derived from RSIVinfected GF cells (Mahardika \& Miyazaki, 2009). However, IBCs derived from RSIV- infected red sea bream has not been described in detail Jung et al., 1997; Sudthongkong et al., 2002 $a, b)$. In the present study, electron microscopic investigations were carried out to study the ultrastructure of IBCs of RSIV-infected spleen tissue of the red sea bream. The morphology and morphogenesis of RSIV were also observed within splenocyte cells.

\section{MATERIAL AND METHOD}

\section{Diseased Red Sea Bream}

Twenty diseased red sea breams (body weight: $30-50 \mathrm{~g}$ ) that were in moribund state or had just died were collected from 2 net cage platforms in Ise bay of Mie Prefecture, Japan in September 21 and 22, 2006. Diseased fish were previously confirmed to be infected by RSIV based on several clinical signs such as severe anemia, petechia of the gill, and enlargement of the spleen, as well as positive result of PCR assay for RSIV. Although a few trichodina- like ciliates were observed on the gills in some examined fish, no bacteria were isolated from the spleen (Shinji Tanaka, personal communication).

\section{PCR Analysis}

The spleens of 10 diseased fish were processed for PCR analysis. DNA templates were extracted from about 10- 20 mg of spleen tissue using ISOGEN (Wako Nippon Gene, Osaka, Japan) according to the manufacturer's protocol. In the present study, the primer sets (1- F and $1-R$ ), which were derived from the DNA sequence of the 959- bp Pst I fragment of RSIV (Kurita et al., 1998) were used. The PCR amplification was performed under conditions described previously by Sudthongkong et al. 
(2002b). Using this PCR test, amplification products of about $570 \mathrm{bp}$ were generated.

\section{Histopathological Examination}

Pieces of the visceral organs (spleen, kidney, liver, and digestive tracts) were fixed in $10 \%$ phosphate- buffered formalin for histopathological examination. The fixed tissues were prepared according to Jung et al. (1997).

\section{Electron Microscopic Examination}

Tissue samples of the diseased fish were fixed in 70\%Karnovsky's solution, post-fixed in $1 \% \mathrm{OsO}_{4}$ and processed for examination under electron microscope according to the method of Sudthongkong et al. (2002a).

\section{RESULT AND DISCUSSION}

\section{Diseased Fish}

The red sea bream mortality occurred during the summer season. The cumulative mortality reached about $50 \%$ to $70 \%$ in 2 net cage platforms. Individual diseased fish usually showed petechia of the gill and enlargement of the spleen. These findings were similar to those reported by Dr. Shinji Tanaka (personal communication) as well as the other scientists
(Inouye et al., 1992; Nakajima et al., 1994; Jung et al., 1997).

\section{PCR Analysis}

A number of primer sets specific for RSIV have been designed based on the ATPase gene, DNA polymerase gene, ribonucleotide reductase small subunit and Pst I restriction fragments of virus genomic DNA (Miyata et al., 1997; Kurita et al., 1998; Oshima et al., 1998). In this study, one RSIV specific primer set, 1- F and 1 - R was used in the PCR designed to identify suspected viral nucleic acid in the tissues of infected fish. A PCR product of about 570 bp was amplified using the 1- F and 1- R primer set with DNA template obtained from affected tissues. Alternatively, no product was found when using the tissues of healthy fish as a template (negative control). These results indicated that the viral agent in the cultured red sea bream was related to the RSIV (Figure 1).

\section{Histopathological Examination}

Of the 20 diseased fish, all spleens contained many enlarged cells as well as necrotized cells (Figure 2A, B). The spleens also contained focal or diffuse hemorrhage and melano- macrophage center (Figure 2C). In the

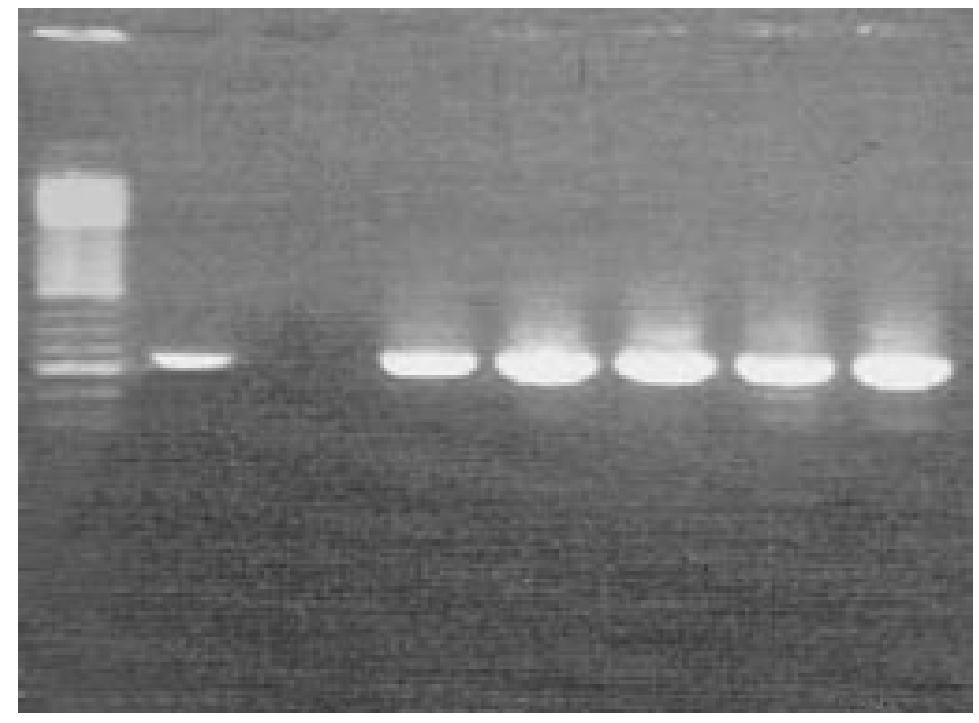

Figure 1. Putative PCR amplicons derived from DNA extract of the spleens of naturally moribund or dead fish (lane: 1 to 5). These results indicated that red sea bream were infected by RSIV (red sea bream iridovirus). M: marker, P: positive control, N: negative control 

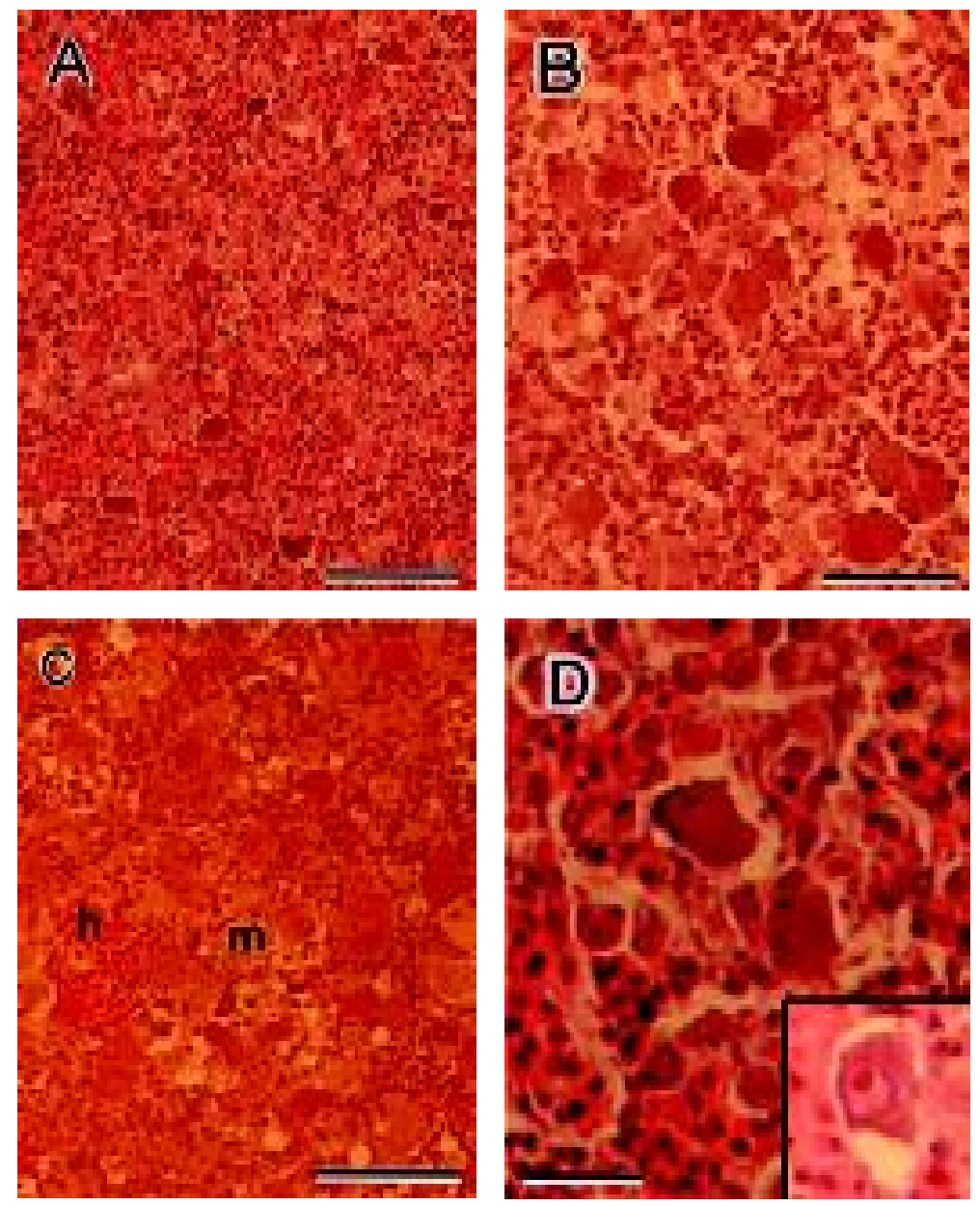

Figure 2. (A) Spleen of the RSIV-infected red sea bream shows massive formation of enlarged cells, necrotized plenocytes and diffuse hemorrhage (H\&E; scale bar $=50 \mathrm{~mm}$ ). (B) High magnification of enlarged cell observed in the spleen tissue (H\&E; scale bar= $35 \mathrm{~mm}$ ). (C) Spleen of the diseased fish contains a mass of melanomacrophage center $(\mathrm{m})$ and focal hemorrhage $(\mathrm{f})$ within formation of enlarged cells and necrotized splenocytes (H\&E; scale bar= $50 \mathrm{~mm}$ ). (D) High power view of typical IBC (inclusion body bearing cell), nucleus of host cell is marginally compressed (black color) (H\&E; scale bar $=20 \mathrm{~mm}$ ). Insert, atypical IBC forms nucleus- like structure in the central of cell, while nucleus of the host cell was pyknotic and marginally compressed.

kidney, many enlarged cells appeared in the hematopoietic tissues and glomerular capillary. Some enlarged cells infiltrated into the liver and tunica propria mucosae and submucosae of the digestive tracts. These enlarged cells contained basophilic inclusion body within the cytoplasm, whose nucleus located at the periphery (Figure 2D). These enlarged cells were named as inclusion body bearing cells (IBCs)
(Jung et al., 1997; Sudthongkong et al., 2002 a,b; Mahardika et al., 2004, 2008; Miyazaki, 2007).

\section{Electron Microscopy Examination}

Under electron microscope, typical IBCS had an intracytoplamic inclusion body, which was delimited from the host- cell cytoplasm by 
a thin membranous boundary. Early stage of IBCs formed dark matrix of a small inclusion body with few virions. Host cell nucleus became marginally compressed (Figure 3A). Mature IBCs had an enlarged inclusion body containing a developed virus assembly site (VAS), abundant mitochondria, ribosome, smooth endo plasmic reticulum (sER), rough granules and/ or smooth granules with high electron density. The host cell cytoplasm was marginally located and contained mitochondria, ribosome, sER and nucleus with irregular shapes (Figure 3B, 3C). Markedly enlarged IBCs had a markedly enlarged inclusion body containing a developed VAS, many mitochondria, sER, ribosome, and masses of rough granules (Figure 3D). Another markedly enlarged IBCs, showed a marginally compressed nucleus and cytoplasm surrounding an enlarged inclusion body. Their inclusion bodies had a centrally located VAS, abun-
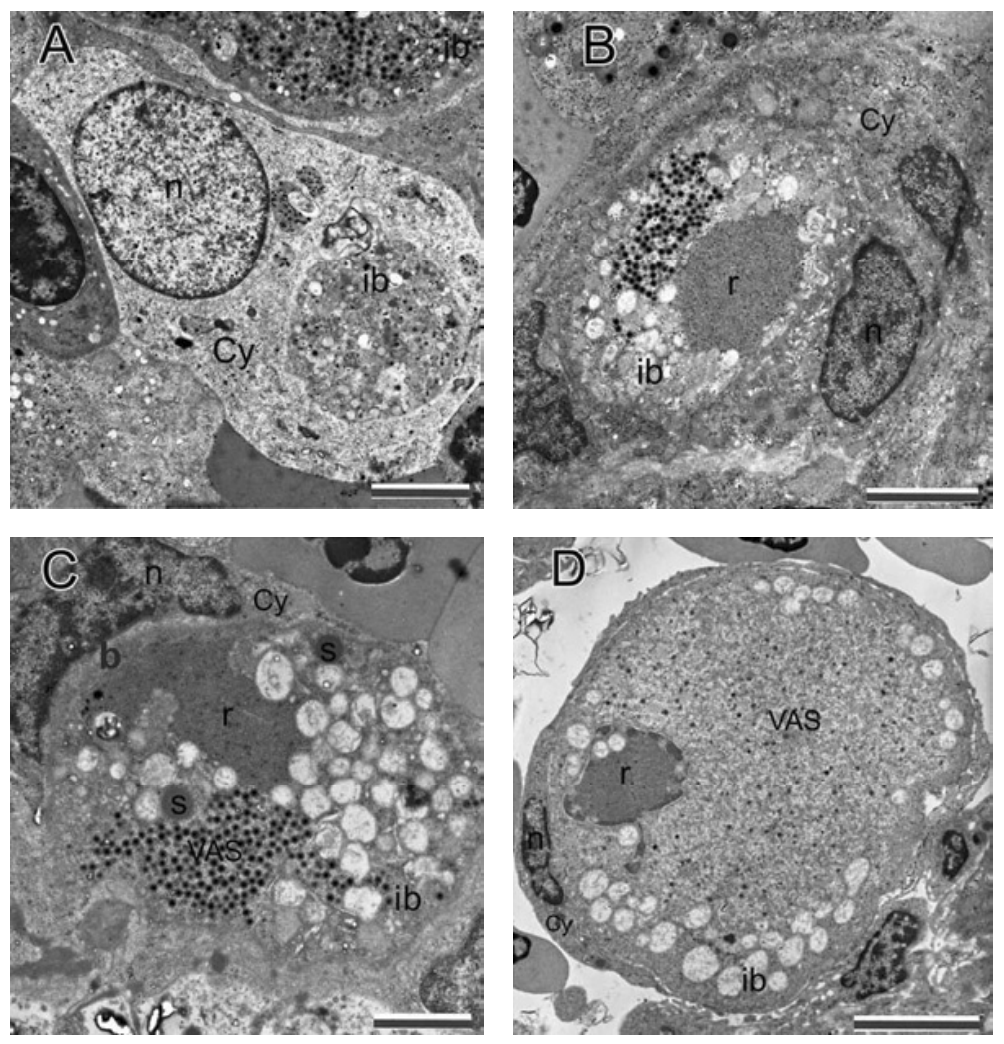

Figure 3. Electron micrograph of spleen tissue of the diseased fish. (A) Early stage of IBC forms dark matrix of a small inclusion body with few virions. Host cell nucleus became marginally compressed (scale bar $=2,000 \mathrm{~nm}$ ). (B) Small mature IBC has an inclusion body containing a developed virus assembly site (VAS). VAS contains mass of rough granules containing viral DNA and assembly of virus particles (scale bar $=2500 \mathrm{~nm}$ ). (C) Small mature IBC has an intracytoplasmic inclusion body which delimited from the host- cell cytoplasm by a thin membranous boundary. It inclusion body contains developed VAS with virions propagation, abundant mitochondria, ribosome, sER, and rough and smooth granules. Host cell nucleus is marginally compressed with irregular shape (scale bar $=2,500 \mathrm{~nm}$ ). (D) Mature IBC has an enlarged inclusion body containing rough granules that resemble a nucleus but had no surrounding double membranes, and developed VAS with propagated virions (scale bar= 3,600 nm). b: boundary membrane; Cy: cytoplasm of host cell; ib: inclusion body; $n$ : nucleus of host cell; r: rough granules; s:smooth granules; RBC: red blood cell; VAS: virus assembly site 
dant ribosomes, mitochondria, sER and masses of rough and smooth granules (Figure 4A, 4B). The highly ballooning cells had an inclusion body with a clear appearance within the surrounding thinned cytoplasm. Their inclusion body contained degenerated and fragmented organelles and a decreased number of virions in the VAS (Figure 4C). Masses of rough and smooth granulars were fragmented among VAS and budding virions on the surface of the host cell cytoplasm. The VAS of mature IBCs had an electron- lucent matrix with abundant fine gran- ules, microfilament, and multiple virus particles. Morphology and morphogenesis of the virus were detected. In the VAS, filamentous- filled virions, partially-filled virions, and hexagonal fully- filled virions (complete virions) were observed among microfilaments and fine granules (Figure 4D, 5A). Filamentous- filled virions had filamentous nucleoprotein core with capsid without definite capsomers. Partiallyfilled virions were a little hexagonally deformed and comprised the partially package of an electron- dense core within the capsid without defi-
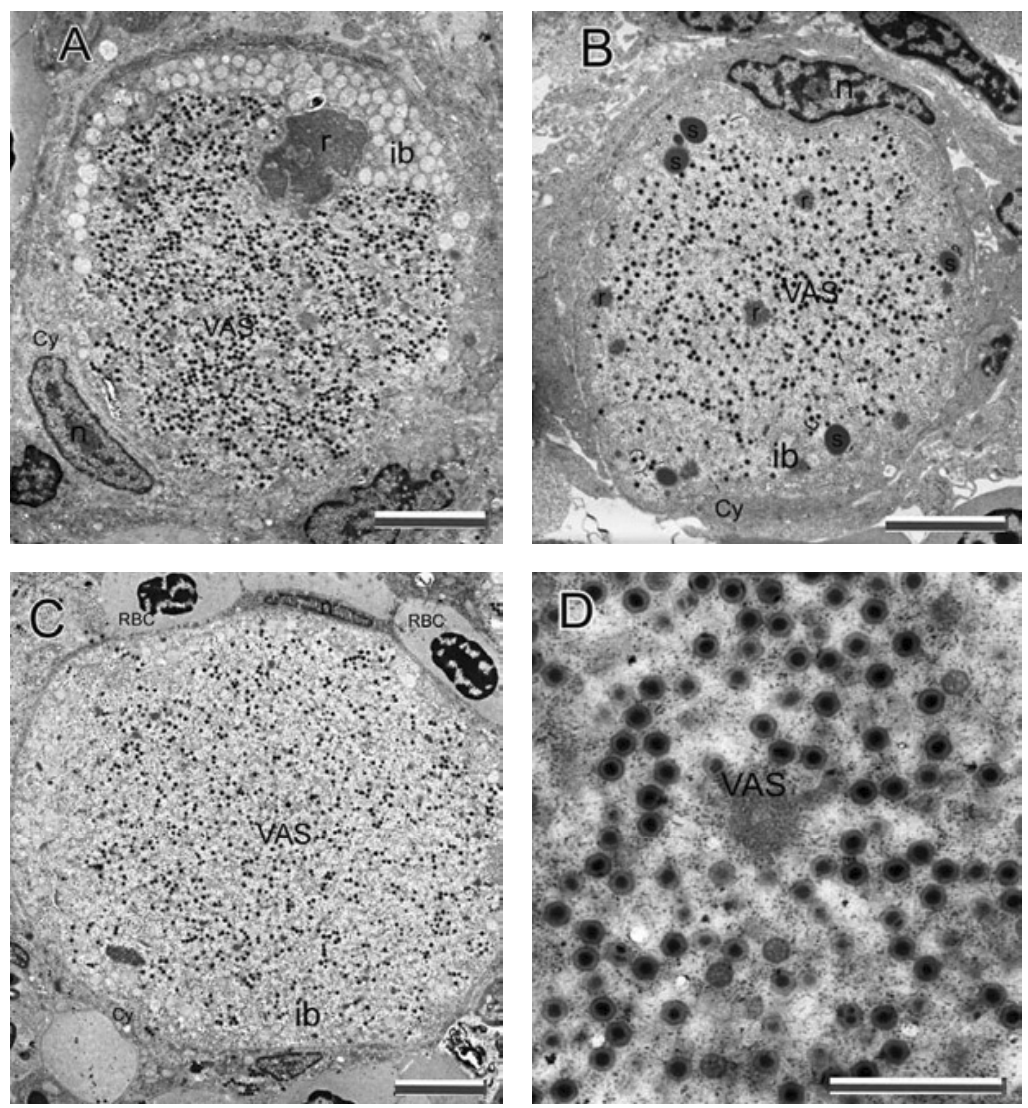

Figure 4. Electron micrograph of spleen tissue of the diseased fish. (A) Mature IBC with markedly enlarged inclusion body contains VAS with fully virions, mitochondria, ribosome and rough granules beside VAS (scale bar $=3,700 \mathrm{~nm}$ ). (B) Enlarged IBC with an inclusion body contains VAS with many virions at all morphogenesis steps. Rough and smooth granules are fragmented within VAS (scale bar $=3,500 \mathrm{~nm}$ ). (C) The highly ballooning cell has an inclusion body with a clear appearance within the surrounding thinned cytoplasm. It inclusion body contains degenerated and fragmented organelles and a decreased number of virions within VAS (scale bar= $3,500 \mathrm{~nm}$ ). (D) High- power view of viral assembly site (VAS). It contains fine granules and microfilaments with assembly of RSIV virions (scale bar $=1,200 \mathrm{~nm}$ ). Abbreviations as in Figure 3 

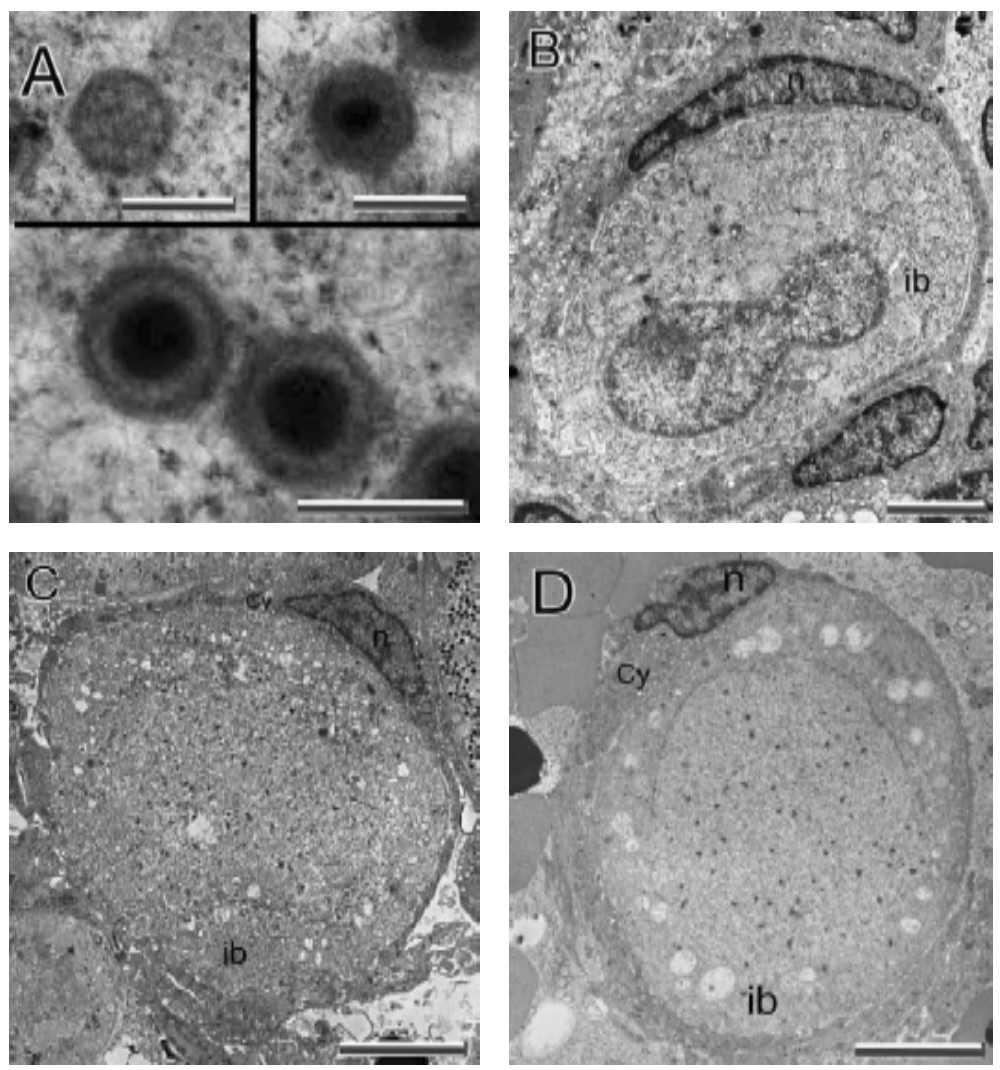

Figure 5. Electron micrograph of spleen tissue of the diseased fish. (A) Detailed features of virus particles in all stages of morphogenesis within the VAS of IBC. There are filamentous- filled virions, partially-filled virions, and hexagonal fully- filled virions (complete virions) with the size of 145 to $150 \mathrm{~nm}$ (scale bar= $150 \mathrm{~nm}$ ). (B) Atypical IBC, the host cell cytoplasm surrounded an inclusion body with the electronlucent matrix containing abundant granules, mitochondria, rER, and a swollen nucleus- like structure (scale bar $=2,500 \mathrm{~nm}$ ). (C) Atypical IBC with inclusion body contains fragmented of masses of granules without nucleus- like structure (scale bar= 3,500 nm). (D) Atypical IBC has inclusion body without the formation of VAS and it degenerates without virion assembly (scale bar $=3,600 \mathrm{~nm}$ ). Abbreviations as in Figure 3

nite capsomers. Complete virions were 145$150 \mathrm{~nm}$ in size, comprising, in turn, a complete package of an electron-dense core, and a capsid with capsomers.

Typical IBCs of the red sea bream were mostly the same as those reported previously by other scientists (Jung et al., 1997; Sudthongkong et al., 2002 a,b; Mahardika \& Miyazaki, 2009; Miyazaki, 2007) as well as typical IBCs found in the other members of megalocytivirus (Mahardika et al., 2004, 2009; Miyazaki, 2007). Other viruses, such as Euro- pean catfish virus (ECV; Ranavirus) and Iymphocystis disease virus (LCDV; Lymphocystivirus) in the family of Iridoviridae have been known to form intracytoplasmic inclusion bodies (Hyatt et al., 2000; Miyazaki, 2007). However, the features of these inclusion bodies are completely different from those of the inclusion bodies that are grown in the IBCs of RSIV-infected cells. The early stage of IBCs that had already formed a small inclusion body were the same as those that were observed in RSIV (Jung et al., 1997; Miyazaki, 2007). The feature of inclusion bodies at the 
early stage of IBCs resembled to that of mature IBCs except for few virions or a small number of virions being assembled.

In IBCS, the inclusion bodies are composed of virions, rER, sER, ribosomes, mitochondria and the granular matrix that contains DNA. Chinchar et al. (2005) reported that synthesis of viral DNA viruses of the family Iridoviridae was known to occur within the nucleus and the cytoplasm. Viral DNA replication commences within the nucleus and then newly-synthesized viral DNA molecules are subsequently transported to the cytoplasm where they serve as templates for the formation of concatameric DNA, that is, the second stage DNA synthesis. The morphogenetic stages of RSIV resembled those in other members of megalocytivirus (Chao et al., 2004; Mahardika et al., 2004; Miyazaki, 2007) as well as ranavirus- infected cells (Hyatt et al., 2000; Chinchar, 2002; Chinchar et al., 2005).

Atypical IBCs were also observed, which were different from typical IBCs. The host cell cytoplasm surrounded an inclusion body with the electron- lucent matrix containing abundant granules, mitochondria, rER, and a swollen nucleus- like structure (Figure 5B). Some inclu- sion bodies of atypical IBCs contained fragmented of masses of granules without nucleus- like structure (Figure 5C, 5D). The abnormality of the inclusion body was also substantiated by the formation of none of VAS and it degenerated without virion assembly. This indicated that RSIV infected cells and induced them to produce an IBC. However, some RSIV virus failed to replicate among inclusion bodies and then the IBC was degenerated and fragmented without virus assembly. Similar abnormal IBCs were also observed in GSDIVinfected humpback grouper which was assumed that unknown antiviral factors were performing antiviral activity within the systemic defense system and inhibiting virus assembly in the spleen before the fish became moribund (Mahardika et al., 2004).

Similar to IBCs, necrotized cells were also observed. This cell formed intracytoplasmic VAS without the formation of the distinct inclusion body. In the VAS, large numbers of virions were assembled (Figure 6A, 6B). Some of these cells contained pyknotic nuclei, and other necrotized cells had fragmented nuclei and the nuclear components were assimilated with the cytoplasm, resulting in the disappearance of the nuclei. These cells developed intracy-
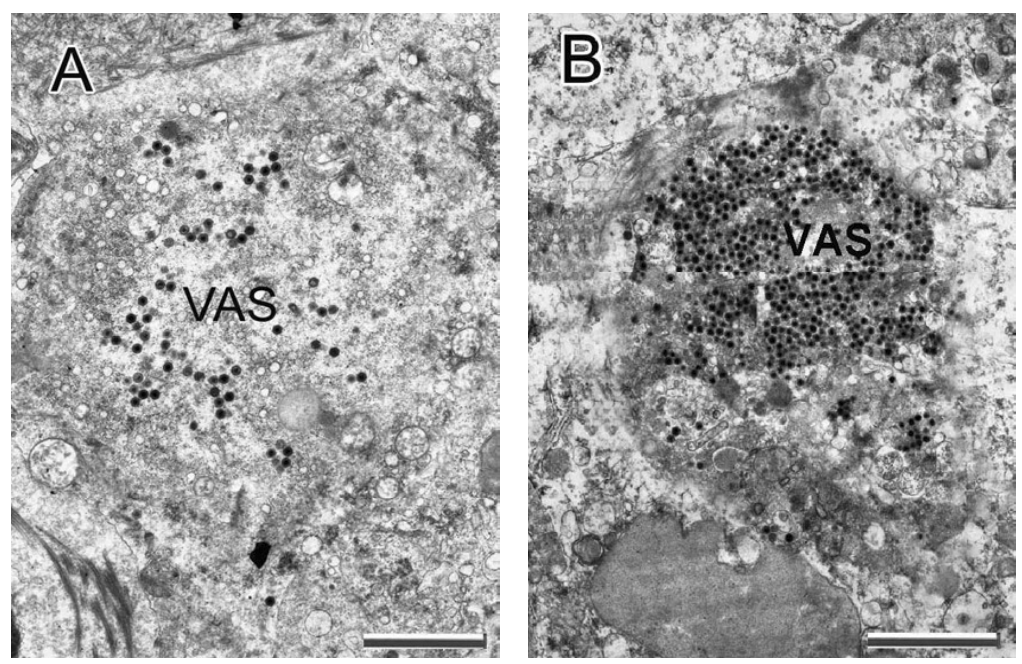

Figure 6. Electron micrograph of the spleen tissue of the diseased fish. (A) A splenocyte infected with RSIV is necrotized with propagation of GSDIV in the cytoplasm. This type of cell have just formed intracytoplasmic VAS, in which some virions are being assembled, without the formation of distinct inclusion body (scale bar $=1,500 \mathrm{~nm}$ ). (A) Necrotized splenocyte contains large number of virus particles within intracytoplasmic VAS. The nucleus has disappeared (scale bar $=2,000 \mathrm{~nm}$ ). Abbreviations as in Figure 3 
toplasmic VASs, within which many virions propagated. This cell was also observed in megalocytivirus- infected red sea bream and grouper fishes (Mahardika et al., 2004; 2009; Miyazaki, 2007; Mahardika \& Miyazaki, 2009). These cells are also one of the characteristics of megalocytivirus infection.

The occurrence of RSIV infection in red sea bream appeared to be correlated with temperature fluctuation. The water temperature had risen when the epizootic mortalities occurred. The RSIV outbreaks in Japan occurred in summer temperatures. However, in Japan, RSIV led to the losses of up to $20 \%-60 \%$ in fingerling and market-sized red sea bream (Nakajima et al., 1998). The spleen and kidney were the most affected organs in the infected fish. Therefore, histopathological observations were consistent with the findings of anaemia and splenomegaly in RSIV-infected red sea bream. Development of typical and atypical IBCs as well as necrotized cells in the spleen and kidney of affected fish characterizes the RSIVD. Morphogenesis of RSIV virus particles were detected in the viral assembly site in both of typical IBCs and necrotic cells. Hexagonal mature or complete virions found in RSIV was 145- $150 \mathrm{~nm}$ in diameter, and thus smaller than TGIV (Chou et al., 1998) and GSDIV from Indonesia (Mahardika et al., 2004). They were similar to RSIV found in cultured GF cells (Mahardika \& Miyazaki, 2009).

In summary, utrastructure investigation is the main step to define the characterization of the RSIV-infected red sea bream. RSIVinfected red sea bream induces typical and atypical IBCs as well as necrotized cells. Typical IBCs and necrotized cells contain virus particles with all morphogenesis steps as immature virions (filamentous filled virion and partially filled virion) and mature virions. While atypical IBCs are degenerated without virus assembly.

\section{ACKNOWLEDGEMENTS}

Author thanks to Prof. Dr. Teruo Miyazaki of Graduate School of Bioresources, Mie University for the opportunity to study at Mie University and his enthusiastic supervision and encouraging advice to all of my research activities and allowed me to publish this data in an Indonesian journal. I also thank Dr. Shinji Tanaka of Mie Prefecture, Fisheries Research Institute, Japan for kindly providing fish sample of RSIV- infected red sea bream, and all students at the Laboratory of Fish Pathology, Graduate School of Bioresources, Mie University for their kind help in preparation of fish samples.

\section{REFERENCES}

Caipang, C.M., Hirono, I., \& Aoki, T. 2003. Development of a real- time PCR assay for the detection and quantification of red seabream iridovirus (RSIV). Fish Pathol., 38: 1-7.

Chao, C.B., Chen, C.Y., Lai, Y.Y., Lin, C.S., \& Huang, H.T. 2004. Histological, ultrastructural, and in situ hybridization study on enlarged cells in grouper Epinephelus hybrids infected by grouper iridovirus in Taiwan (TGIV). Dis. Aquat. Org., 58: 127- 142.

Chinchar, V.G. 2002. Ranaviruses (family Iridoviridae): Emerging cold- blooded killers. Arch. Virol., 147: 447- 470.

Chinchar, G., Essbauer, S., He, J.G., Hyatt, A., Miyazaki, T., Seligy, V., \&Williams, T. 2005. Family Iridoviridae. In: Fauquet, C.M., M.A. Mayo, J. Maniloff, U. Desselberger, and L.A. Ball (Eds.) Virus Taxonomy. Classification and Nomenclature of Viruses. Eighth Report of the International Committee on the Taxonomy of Viruses. Academic Press, San Diego, p. 145- 162.

Chinchar, V.G., Hyatt, A., Miyazaki, T., \& Williamsm T. 2007. Family Iridoviridae: Poor viral relations no longer. CTMI, 18 October, p. 1-64.

Chou, H.Y., Hsu, C.C., \& Peng, T.Y. 1998. Isolation and characterization of a pathogenic iridovirus from cultured grouper (Epinephelus sp.) in Taiwan. Fish Pathol., 33: 201- 206.

Dang Thi, L., Yasuike, M., Hirono, I., Kondo, H., $\&$ Aoki, T. 2007. Transcriptional profile of red sea bream iridovirus in a fish model as revealed by viral DNA microarrays. Virus Genes, 35: 449-461.

Go, J., Lancaster, M., Deece, K., Dhungyel, O., \& Whittington, R. 2006. The molecular epidemiology of iridovirus in Murray cod (Muccullochella peeli peelii) and dwarf gourami (Colisa lalia) from distant biogeographical regions suggests a link between trade in ornamental fish and emerging iridoviral diseases. Mol Cell Probes, 20: 212- 222.

He, J.G., Deng, M., Weng, S.P., Li, Z., Zhou, S.Y., 
Long, Q.X., Wang, X.Z., \& Chan, S.M. 2001. Complete genome analysis of the mandarin fish infectious spleen and kidney necrosis iridovirus. Virology, 291: 126- 139.

Hyatt, A.D., Gould, A.R., Zupanovic, Z., Cunningham, A.A., Hengstberger, S., Whittington, R.J., Kattenbelt, J., \& Coupar, B.E.H.. 2000. Comparative studies of piscine and amphibian iridoviruses. Arch. Virol., 145: 301- 331.

Imajoh, M., Sugiura, H., \&Oshima, S. 2004. Morphological changes contribute to apoptotic cell death and are affected by caspase- 3 and caspase- 6 inhibitors during red sea bream iridovirus permissive replication. Virology, 322: 220-230.

Imajoh, M., Ikawa, T., \& Oshima, S. 2007. Characterization of a new fibroblast cell line from a tail fin of red sea bream, Pagrus major, and phylogenetic relationships of a recent RSIV isolate in Japan. Virus Res., 126: 45- 52.

Inouye, K., Yamano, K., Maeno, Y., Nakajima, K., Matsuoka, M., Wada, Y., \& Sorimachi, M. 1992. Iridovirus infection of cultured red sea bream, Pagrus major. Gyobyo Kenkyu, 27: 19- 27.

Jung, S.J., Miyazaki, T., Miyata, M., Danayadol, Y., \& Tanaka, S. 1997. Pathogenicity of iridovirus from Japan and Thailand for the red sea bream Pagrus major. Fish Sci., 63: 735- 740 .

Jung, S.J. \& Oh, M.J. 2000. Iridovirus-like infection associated with high mortalities of striped beakperch, Oplegnathus fasciatus (Temminck et Schlegel), in southern coastal areas of the Korean Peninsula. J. Fish Dis., 23: 223- 226.

Kawakami, H. \& Nakajima, K. 2002. Cultured fish species affected by red sea bream iridoviral disease from 1996 to 2000 . Fish Pathol., 37: 45- 47 (in Japanese with English abstract).

Kurita, J., Nakajima, K., Hirono, I., \&Aoki, T. 1998. Polymerase chain reaction (PCR) amplification of DNA of red sea bream iridovirus (RSIV). Fish Pathol., 33: 17- 23.

Kurita, J., Nakajima, K., Hirono, I., \&Aoki, T. 2002. Complete genome sequencing of red sea bream Iridovirus (RSIV). Fisheries Sci., 68 (Suppl. II): 1113- 1115.

Lu, L., Zhou, S.Y., Chen, C., Weng, S.P., Chan, S.M., \& He, J.G. 2005. Complete genome sequence analysis of an iridovirus isolated from the orange-spotted grouper, Epinephelus coioides. Virology, 339: 81- 100.

Mahardika, K., Zafran, Yamamoto, A., \& Miyazaki, T. 2004. Susceptibility of juvenile humpback grouper (Cromileptes altivelis) to grouper sleepy disease iridovirus (GSDIV). Dis. Aquat. Org., 59: 1- 9.

Mahardika, K., Haryanti, Muzaki, A., \& Miyazaki, T. 2008. Histopathological and ultrastructural features of enlarged cells of humpback grouper Cromileptes altivelis challenged with Megalocytivirus (Family Iridoviridae) after vaccination. Dis. Aquat. Org., 79: 163- 168.

Mahardika, K. \& Miyazaki, T. 2009. Electron microscopic features of cultured grunt fin cells infected with Megalocytivirus. Aquaculture Sci., 57: 9- 18.

Mahardika, K., Muzaki, A., \& Suwirya, K. 2009. Pathogenecity of grouper sleepy disease iridovirus (GSDIV: Megalocytivirus, family Iridoviridae) to coral trout grouper Plectrophomus leopardus. Indonesian Research Journal, Inpres.

Matsuoka, S., Inouye, K., \& Nakajima, K. 1996. Cultured fish species affected by red sea bream iridoviral disease from 1991 to 1995. Fish Pathol., 31: 233- 234 (in Japanese with English summary).

Miyata, M., Matsuno, K., Jung, S.J., Danayadol, Y., \& Miyazaki, T. 1997. Genetic similarity of iridoviruses from Japan and Thailand. J. Fish Dis., 20: 127- 134.

Miyazaki, T. 2007. Color Atlas of Fish Histopathology, Vol. 2. Shin-Suisan Shimbun- Sha, Tokyo, Japan, p. 325- 335.

Nakajima, K. \& Sorimachi, M. 1994. Biological and physico-chemical properties of the iridovirus isolated from cultured red sea bream, Pagrus major. Fish Pathol., 29: 2933.

Nakajima, K., Inouye, K., \& Sorimachi, M. 1998. Viral diseases in cultured marine fish in Japan. Fish Pathol., 33: 181- 188.

Oshima, S., Hata, J., Hirasawa, N., Ohtaka, T., Hirono, I., Aoki, T., \&Yamashita, S. 1998. Rapid diagnosis of red sea bream iridovirus infection using the polymerase chain reaction. Dis. Aquat. Org., 32: 87- 90.

Piaskoski, T.O. \& Plumb, J.A. 1999. Characterization of the largemouth bass virus in cell culture. J. Aquat. Anim. Health, 11: 45- 51.

Sohn, S.G., Choi, D.L., Do, J.W., Hwang, G.Y., \& Park, J.W. 2000. Mass mortalities of cultured 
striped beakperch, Oplegnathus fasciatus by iridoviral infection. J. Fish Pathol., 13(2): 121- 127 (in Korean with English abstract).

Song, J.Y., Kitamura, S- I., Jung, S.J., Miyadai, T., Tanaka, S., Fukuda, Y., Kim, S.R., \& Oh, M.J. 2008. Genetic variation and geographic distribution of megalocytiviruses. J. Microbiology, 46: 29- 33.

Sudthongkong, C., Miyata, M., \& Miyazaki, T. 2002a. Iridovirus disease in two ornamental tropical freshwater fishes: African lampeye and dwarf gourami. Dis. Aquat. Org., 48: 163- 173.

Sudthongkong, C., Miyata, M., \& Miyazaki, T. $2002 \mathrm{~b}$. Viral DNA sequences of genes encoding the ATPase and the major capsid protein of tropical iridovirus isolates which are pathogenic to fishes in Japan, South China Sea and southeast Asian countries. Arch. Virol., 147: 2,089-2,109.

Williams, T. 1996. The iridoviruses. Adv. Virus Res., 46: 347- 412. 